(C2020. This manuscript version is made available under the CC-BY-NC-ND 4.0 license http://creativecommons.org/licenses/by-nc-nd/4.0/

\title{
Downstream passage of silver European Eel (Anguilla anguilla) at a pumping
} station with a gravity sluice

\author{
N.J. Baker ${ }^{1}$, R.M. Wright ${ }^{2}$, I.G. Cowx ${ }^{1}$, L.A. Murphy ${ }^{1}$ and J.D. Bolland ${ }^{1}$ \\ ${ }^{1}$ University of Hull International Fisheries Institute, University of Hull, Hull, HU6 7RX \\ ${ }^{2}$ Environment Agency, Rivers House, Threshelfords Business Park, Inworth Rd, Feering, \\ CO5 9SE, UK
}

Corresponding author: Dr Jonathan Bolland; j.bolland@hull.ac.uk

Keywords: catadromous, Anguilla, migration, downstream passage, bypass channel, entrainment

\section{Highlights:}

- Gravity sluices at pumping stations may be a safe downstream passage route for eels

- Only two of seven eels passed through a gravity sluice despite opening daily

- Three passed through pumps despite rarely operating and two retreated upstream

- Long passage delays and a reluctance to pass through pumps was also observed

- The operating regime should be tailored to sluice water when silver eels migrate 


\section{Abstract}

The European eel (Anguilla anguilla (L.)) is critically endangered after a multi-decadal decline. Anthropogenic disruption to downstream migration, including at water control structures such as pumping stations, is thought to be one of the contributing factors. Some pumping stations only operate during floods and river water drains through sluice gates under the influence of gravity ('gravity sluice' hereafter) at all other times. Gravity sluices are considered a safe downstream passage route for downstream migrating silver eels, but it is not known if eels approach or pass through them. This novel study aimed to understand the timing, passage routes and fine-scale behaviour of downstream migrating silver European eel $(n=7)$ immediately upstream of a pumping station with a gravity sluice using acoustic telemetry. During the study, three eels passed through pumps $(42.9 \%)$ despite only operating for $8 \%$ of the time that the gravity sluice was open, two passed through the gravity sluice (28.6\%) and the remaining two retreated upstream (28.6\%). Long passage delays (up to 21 days) were observed and eels were detected retreating back upstream (up to 10 times) prior to passing downstream. It is recommended that operational changes are implemented to make the gravity sluice a more attractive downstream passage route for downstream migrating silver eels and thus reduce passage through hazardous pumps.

\section{Introduction}

River levels in many industrialised countries are controlled by pumping stations, especially for societal flood protection and irrigation (Baumgartner et al., 2009; Buysse et al., 2014), which can cause considerable disruption to downstream migration of fishes. The Anguilla genus are heavily impacted because they have a catadromous life cycle and must safely navigate migration barriers in-river, such as pumping stations, during the downstream migration to oceanic spawning grounds (Verhelst et al., 2018). Downstream migrating adult silver European eel (Anguilla anguilla (L.)) abundance decreased by as much as $90 \%$ between 1975 and 2010 (Bevacqua et al., 2015) with human-mediated activities such as pumping stations being a contributing factor to this decline (Feunteun, 2002; Calles et al., 
2010; Piper et al., 2013). This has led the International Union for Conservation of Nature to classify the species as Critically Endangered (Jacoby and Gollock, 2014). In 2007, the European Commission developed specific legislation (Council Regulation (EC) No. 1100/2007) to protect eels. This is enacted in England through the Eels (England and Wales) Regulations 2009 Statutory Instrument (Eels Regulations), which includes requirements for eel passage and screening of water intakes (including pumping stations) abstracting $>20 \mathrm{~m}^{3} /$ day, unless exempted by the Environment Agency (the regulator). Eel measures for compliance with Eels Regulations or agreed alternative measures should be implemented in planned programmes of work at pumping stations or exempted if they are found to pose no risk to eel (Solomon and Wright, 2012).

Often, the only downstream passage route at a pumping station is through pumps, which can cause injury or mortality (Bolland et al., 2019). Some pumping stations, however, only operate during floods and river water drains through sluice gates under the influence of gravity ('gravity sluice' hereafter) at all other times (e.g. 44 of 125 in Anglian region of England; Solomon and Wright, 2012). Gravity sluices are considered a safe downstream passage route for eels, and are increasingly recognised as a low-cost passage solution at hydropower facilities (Egg et al., 2017; Okland et al., 2019; Baker et al., 2020), but it is not known if eel approach or pass through them at pumping stations. This novel study aimed to determine whether seaward-migrating silver European eel approach and pass through a gravity sluice or the pumps at a pumping station (with a normal operating regime). More specifically, fine-scale acoustic telemetry enabled the approach, retreat and passage movements of tagged eels to be directly related to when the gravity sluice was open and the pumping station was in operation. Such information is urgently required to establish if gravity sluices at pumping stations (with normal operating regime) are an acceptable alternative measure to allow safe eel passage, or if remediation measures are required. 


\section{Materials and methods}

Five Towns pumping station (Latitude: 2.871898, Longitude: -0.044521 ) drains the Five Towns Drain into the tidal River Welland in Eastern England. It was commissioned in 1962 to provide flood protection to the $32 \mathrm{~km}^{2}$ catchment using three, $1.07 \mathrm{~m}$ diameter, $1.7 \mathrm{~m}^{3} / \mathrm{sec}$ capacity, mixed flow pumps. Under the current operational regime, the upstream river level is primarily controlled by gravity drainage by manually removing stop blocks from a surface-oriented sluice adjacent to the pumps. Pointing doors downstream of the gravity sluice prevent upstream ingress during high downstream river level. The upstream channel is $\sim 1.5 \mathrm{~m}$ deep and the pumping station has a trash screen with $12 \mathrm{~mm}$ thick bars and 50 $\mathrm{mm}$ spaces to protect the pumps. During the study period (31 October 2016 - 26 November 2016), the gravity sluice was open every day for a total of $\sim 59$ hours (daily average $=02: 27$ hours per day), though the duration of sluicing each day varied considerably depending on downstream tide level $(\min -\max =00: 18-12: 45$ hours per day). There were five pumping events during the study period which equated to 12:08 hours of pumping ( $\min -\max =00: 02$ - 05:17), of which 11:59 hours were between 20:55 on 21 November and 20:10 on 23 November (25.4\% of this time) and the remaining 9 minutes occurred on 14 (4 minutes) and 15 (5 minutes) November.

Seaward-migrating adult silver eels $(n=7)$ were caught using fyke nets emptied weekly in the reach $100 \mathrm{~m}$ upstream of the pumping station $(31$ October $=2,7$ October $=1$ and 21 November $=4)$. Prior to tagging in the field, acoustic transmitters $(25 \mathrm{~mm}$ long $\mathrm{x} 9 \mathrm{~mm}$ diameter, $3.7 \mathrm{~g}$ weight in air (less than $2 \%$ of fish mass), $180 \mathrm{kHz}$, High Residence (HR) delay $=1-2$ and Pulse Position Modulation (PPM) delay $=50-70$ seconds, and expected battery life $=170$ days; www.vemco.com) were activated, tested with a hand held receiver (Vemco VR100) to verify that they were transmitting, disinfected with Providone-iodine and rinsed with saline solution. Eels were anaesthetised using buffered tricaine methanesulphonate (MS-222; 0.16-g per $10 \mathrm{~L}$ of river water). Once anaesthetised, each eel was weighed $(\mathrm{g})$ before being placed in a clean V-shaped foam support. Total length, left 
pectoral fin length, head width, left eye horizontal and vertical diameters (all in $\mathrm{mm}$ ) were measured. A ventro-lateral incision was made with a scalpel anterior to the muscle bed of the anal fins, an acoustic tag was implanted into the body cavity and the incision was closed with an absorbable monofilament suture. After surgery, fish were continuously monitored in a well-aerated tank of fresh river water and were released $\sim 200 \mathrm{~m}$ upstream of the pumping station after full recovery (regained balance and actively swimming). Maturation stage was later calculated following methods of Durif et al., (2009), i.e. FII = 2, FIII = 2 and FV = 3; all eels were determined to be in the migratory phase. All fish were treated in compliance with the UK Animals (Scientific Procedures) Act 1986, Home Office licence number PPL 60/4400.

An autonomous underwater acoustic telemetry array consisting of eight receivers $(6 \times \mathrm{HR} 1$ and 2 x HR2; Vemco, Halifax, Canada) was installed immediately upstream of the pumping station. For fine-scale position analysis, a Horizontal Position Error (HPE) <2 filter was applied (10.3\% of all positions retained). Downstream passage route (gravity sluice or pump) was determined for each eel using the final position in the array; it was not safe to deploy a receiver in the tidal river downstream. In three cases, tagged eels (tag IDs 35825, 35826 and 35827) were recaptured in fyke nets upstream of the pumping station (intended to catch eels for tagging) and were re-released $\sim 200 \mathrm{~m}$ upstream of the pumping station and time in nets was excluded from analysis. A series of metrics were calculated for each eel (Table 1).

Table 1. Metrics used to analyse eel movements at Five Towns pumping station.

\begin{tabular}{|c|c|}
\hline Metric & Calculation \\
\hline Time to approach & $\begin{array}{l}\text { Difference in time between release and first detection in the receiver } \\
\text { array upstream of the pumping station. }\end{array}$ \\
\hline $\begin{array}{l}\text { Time from } \\
\text { release to last } \\
\text { detection }\end{array}$ & $\begin{array}{l}\text { Difference in time between release and last detection in the receiver } \\
\text { array upstream of the pumping station. }\end{array}$ \\
\hline Passage time & $\begin{array}{l}\text { Difference in time between first and last detection in the receiver array } \\
\text { upstream of the pumping station for eels that passed downstream. }\end{array}$ \\
\hline
\end{tabular}


Relative passage Passage time as a proportion of time from release to last detection for time eels that passed downstream.

Number of array Count of when the interval between individual eel positions (HPE $<2$ visits filter applied) in the array was greater than 30 minutes.

Duration of array Difference in time between first and last position in the receiver array visits during each visit (HPE<2 filter applied).

Total time in array Sum of all array visits.

Route availability Total time a downstream passage route (i.e. gravity sluice and pump) was available when eels were in the array.

To analyse whether time from release to last detection and passage time differed between route taken, independence permutation tests were used (referred to as independence-test) due to sample sizes being small (Hothorn et al., 2008, and references therein). During the eel's final visit to the pumping station before passage, or 'passage track', the beeline distance (distance between the eel position and downstream passage route (i.e. gravity sluice and pump)) was plotted against the backward path length (path taken by eels prior to downstream passage). All statistical analyses were carried out in R studio v 3.3.0 including the use of the package coin (Hothorn et al., 2006).

\section{Results}

All tagged eels ( $n=7$ ) approached the pumping station; time to approach the pumping station after release ranged from less than 2 hours to over 6 days. Only one eel (tag ID 35831) was first detected at the pumping station during daylight and all eels were last detected during hours of darkness (Table 2). Two eels passed through the gravity sluice (28.6\%), three passed through the pumping station $(42.9 \%)$ and two did not pass, i.e. retreated upstream (28.6\%). Eels took between 3 hours and 2.35 days from release to pass through the gravity sluice and passage time for these two eels was 5 and 38 minutes, respectively, which equated to 2.9 and $1.1 \%$ of the time at liberty (Table 2). Eels took 10.04 hours, 16.02 days and 21.40 days from release to pass through pumps and passage time was $09.12,9.91$ days and 21.30 days, respectively, which equated to $84.1,61.9$ and $99.5 \%$ of the time at liberty (Table 2). Time from release to last detection (independence-tests; $Z$ = 
1.256, $n=5, P=0.209)$ and passage time $(Z=1.228, n=5, P=0.219)$ were comparable for eels that passed through the gravity sluice and pumps. Two eels that did not exit the catchment were last detected upstream of the pumping station 4 and 24 days after release on 25 and 24 November, respectively.

Table 2. Eel tag ID, fate $(G=$ gravity sluice, $P=$ pumps, $N P=$ no passage $)$ of tagged European eel at Five Towns pumping station, including time to approach (days hours:minutes), time of first and last detection (hours:minutes), time from release to last detection (days hours:minutes), passage time (days hours:minutes) and relative passage time (\%).

\begin{tabular}{llllllll}
\hline $\begin{array}{l}\text { Eel } \\
\text { tag ID }\end{array}$ & Fate & $\begin{array}{l}\text { Time of } \\
\text { first } \\
\text { detection }\end{array}$ & $\begin{array}{l}\text { Time to } \\
\text { approach }\end{array}$ & $\begin{array}{l}\text { Time of } \\
\text { last } \\
\text { detection }\end{array}$ & $\begin{array}{l}\text { Time from } \\
\text { release to } \\
\text { last detection }\end{array}$ & $\begin{array}{l}\text { Passage } \\
\text { time }\end{array}$ & $\begin{array}{l}\text { Relative } \\
\text { passage } \\
\text { time (\%) }\end{array}$ \\
\hline 35830 & G & $16: 59$ & 00d 02:59 & $17: 04$ & 00d 03:05 & 00d 00:05 & 2.9 \\
35828 & G & $21: 45$ & 02d 07:45 & $22: 22$ & 02d 08:23 & 00d 00:38 & 1.1 \\
35831 & P & $15: 44$ & 00d 01:44 & $00: 55$ & 00d 10:56 & 00d 09:12 & 84.1 \\
35827 & P & $18: 35$ & 06d 02:35 & $16: 27$ & 16d 00:28 & 09d 21:53 & 61.9 \\
35826 & P & $16: 31$ & 00d 02:32 & $23: 40$ & 21d 09:41 & 21d 07:09 & 99.5 \\
35825 & NP & $16: 35$ & 00d 02:36 & $19: 18$ & 24d 04:57 & - & - \\
35845 & NP & $18: 02$ & 04d 04:02 & $18: 45$ & 04d 04:43 & - & - \\
\hline
\end{tabular}

Overall, the gravity sluice was open for $6.0 \%$ and pumps were operational for $3.9 \%$ of the time eels were detected in the array upstream of the pumping station. Eels that passed through the gravity sluice $(n=2)$ did so during their first approach to the pumping station and experienced no pumping events between release and passage (Table 3). Three eels passed through the pumps after visiting the pumping station two, six and 11 times, and duration of array visits ranged from 00:00 (a single position in the array) to over 4 hours (mean \pm S.D. $=$ $00: 58 \pm 01: 42$, range $=00: 00-4: 19)$ (Table 3). When these three eels were detected in the array, pumps were operational for $100,3.8$ and $10.6 \%$ and the gravity sluice was open for 0 , 
0 and $13.6 \%$ of the time, respectively. For eels that did not pass, one approached the pumping station on 29 separate occasions, which equated to spending a total time of almost 38 hours in the array, including approximately one hour during pump operation and one hour during sluicing. The final eel was not positioned within the receiver array $(\mathrm{HPE}<2$ filter applied) but was detected on 9 occasions $\sim 100$ m upstream.

Table 3. Eel tag ID, fate ( $G=$ gravity sluice, $P=$ pumps, NP = no passage), number of array visits (NAV), duration of array visits (mean \pm S.D. (min. - max.)) (hours:minutes:seconds), total time in array (days hours:minutes:seconds), including relative to passage time (\%), and passage route availability (pumps and gravity sluice) (hours:minutes:seconds), including relative to total time in array (\%). HPE $<2$ filter applied.

\begin{tabular}{|c|c|c|c|c|c|c|}
\hline \multirow[t]{2}{*}{$\begin{array}{l}\text { Eel } \\
\text { tag ID }\end{array}$} & \multirow[t]{2}{*}{ Fate } & \multirow[t]{2}{*}{ NAV } & \multirow[t]{2}{*}{$\begin{array}{l}\text { Duration of array } \\
\text { visits (mean } \pm \text { S.D. } \\
(\text { min. }- \text { max.)) }\end{array}$} & \multirow[t]{2}{*}{$\begin{array}{l}\text { Total time in array } \\
\text { (relative to } \\
\text { passage time, \%) }\end{array}$} & \multicolumn{2}{|c|}{$\begin{array}{l}\text { Route availability } \\
\text { (relative to total time } \\
\text { in array, \%) }\end{array}$} \\
\hline & & & & & Pump & Gravity \\
\hline 35830 & $G$ & 1 & $00: 03: 13$ & $\begin{array}{l}\text { Od 00:03:13 } \\
(59.4)\end{array}$ & 0 & 0 \\
\hline 35828 & $\mathrm{G}$ & 1 & 00:33:06 & $\begin{array}{l}\text { Od 00:33:06 } \\
(87.7)\end{array}$ & 0 & 0 \\
\hline 35831 & $P$ & 2 & $\begin{array}{l}00: 09: 15 \pm 00: 13: 04 \\
(00: 00: 00-0: 18: 29)\end{array}$ & $\begin{array}{l}\text { Od 00:18:29 } \\
(3.4)\end{array}$ & $\begin{array}{l}00: 18: 29 \\
(100)\end{array}$ & 0 \\
\hline 35827 & $\mathrm{P}$ & 11 & $\begin{array}{l}00: 44: 43 \pm 01: 20: 20 \\
(00: 00: 00-4: 19: 14)\end{array}$ & $\begin{array}{l}\text { Od 08:11:54 } \\
(3.5)\end{array}$ & $\begin{array}{l}00: 18: 51 \\
(3.8)\end{array}$ & 0 \\
\hline 35826 & $P$ & 6 & $\begin{array}{l}00: 23: 14 \pm 00: 24: 13 \\
(00: 02: 00-1: 07: 39)\end{array}$ & $\begin{array}{l}\text { Od 02:19:26 } \\
(0.5)\end{array}$ & $\begin{array}{l}00: 14: 43 \\
(10.6)\end{array}$ & $\begin{array}{l}00: 19: 01 \\
(13.6)\end{array}$ \\
\hline 35825 & NP & 29 & $\begin{array}{l}01: 18: 34 \pm 01: 36: 09 \\
(00: 00: 00-5: 10: 13)\end{array}$ & $\begin{array}{l}\text { 01d 13:58:39 } \\
(6.6)\end{array}$ & $\begin{array}{l}\text { 01:03:09 } \\
(2.8)\end{array}$ & $\begin{array}{l}02: 38: 42 \\
(7.0)\end{array}$ \\
\hline 35845 & NP & - & - & - & - & - \\
\hline
\end{tabular}

Analysis of beeline distance and backward path length during the passage track of two eels that passed through the gravity sluice during their first and only visit to the pumping station 
differed markedly (Figure 1). One eel did not retreat before passage whereas the other retreated 15 times, first retreating from $6 \mathrm{~m}$ upstream of the gravity sluice before moving around the array and last retreating from $1 \mathrm{~m}$ from the trash screen when pumps were not operational; these were the closest approach distances to either passage route. For the three eels that passed through the pumping station, a pump was on for $100 \%$ of the final visit but movements were highly variable. Eels retreated 1,5 and 12 times while inside the array, with the first at a distance of 3,27 and $8 \mathrm{~m}$ from the trash screen, respectively. The location of the final retreat for each eel before passage through pumps was 3,1 and $19 \mathrm{~m}$ from the trash screen before directional movements from 5, 5 and $20 \mathrm{~m}$ upstream, respectively (Figure 1). 

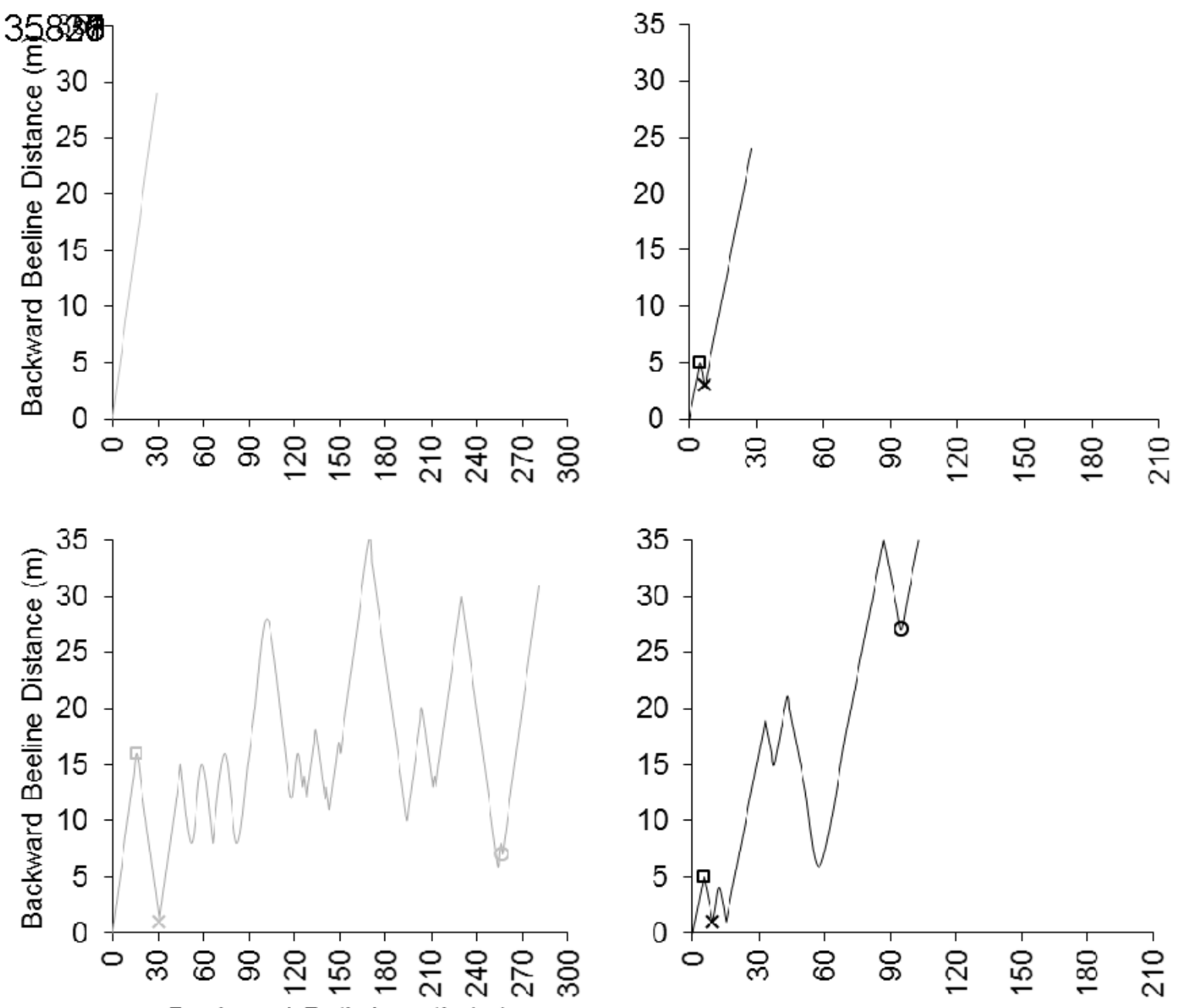
Backward Path Length (m)

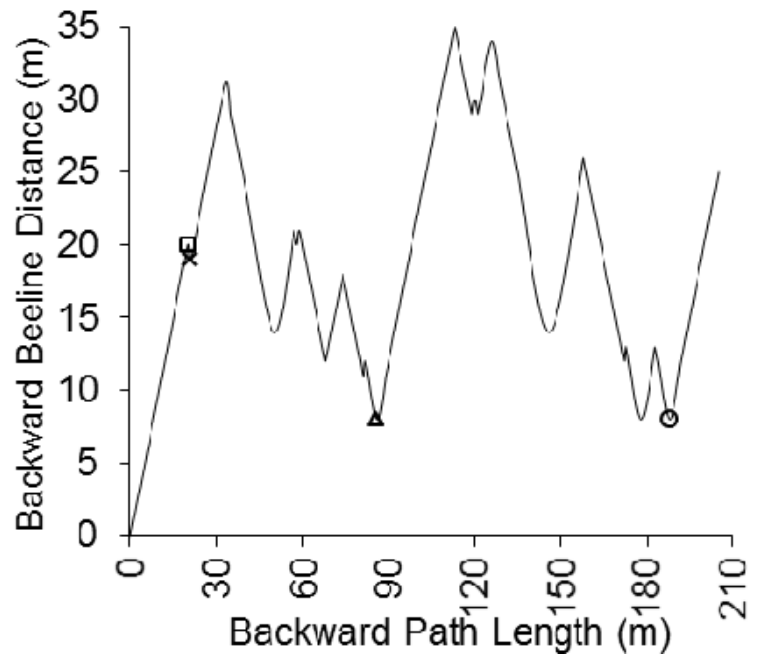


Figure 1. Backward beeline distance $(m)$ in relation to backward path length $(m)$ during the passage track (HPE < 2) for each eel (tag ID top left of each plot) through gravity sluice (left) and pumps (right), including position of first retreat (circle), last retreat (cross), closest approach (triangle) and last approach (square).

\section{Discussion}

During this study, only two of seven acoustic tagged eels (28.6\%) passed through the gravity sluice into the estuary despite it being open on every tide. The low passage rate through the gravity sluice could be attributed to flows not being strong enough to attract migratory eels, which was also reported by Verhelst et al. (2018). The surface-orientated spill for the gravity sluice may also be unsuitable for eels to pass over willingly, potentially preferring an undershot sluice (Egg et al., 2017) or a deep entrance bypass systems (Baker et al., 2019).

Three acoustic tagged eels (42.9\%) passed through the pumping station despite only operating for 14 hours during the study and were assumed to have died; similar pumps have been found to be particularly damaging to eels (Watene and Boubée, 2005; Bolland et al., 2019). Prior to passing through the pump, these three eels performed repeated retreat behaviours, indicating unwillingness to pass through this route. Van Keeken et al., (2020) reported that the majority of European eel that approached a large pumping station performed a turning behaviour at $(44.7 \%)$ or in front of the trash rack (14.7\%). Avoidance behaviour by European eels at water abstraction intakes has been reported in response to different flow fields (Behrmann-Godel and Eckmann, 2003; Jansen, 2007), including constricted flow (Piper et al., 2015), or associated noise and turbulence (Sand et al., 2000). Brown et al., (2009) also reported similar milling and retreat behaviour by American silver eels (Anguilla rostrata) in the forebay of a hydropower station. Migration delays can increase predation risk, worsen the onset of diseases (if present) due to stress, deplete their limited energy reserves (Garcia de Leaniz, 2008; Verhelst et al., 2018) and cause arrest of the 
migration (i.e. revert back to yellow stage; Durif et al., 2005; Bašić et al., 2019). Indeed, the two eels that retreated back upstream (28.6\%) may have reverted back to yellow eels and thus may complete their migration at a later date, but delays may have also caused them to be predated upon.

\section{Conclusions and recommendations}

It was concluded that under the current operating regime (tailored to regulate upstream river level), the gravity sluice was not an efficient downstream passage route for silver European eels. It is hence recommended that the operating regime at pumping stations with a gravity sluice should be tailored to sluice more water when silver eels are known to migrate, i.e. at night during a new moon in autumn and early winter (Tesch, 2003; Sandlund et al., 2017), especially given the low cost of this remediation measure. Where possible, the upstream river level should be elevated (without increasing flood risk) prior to sluicing to increase the depth of water passing over the sluice, duration of sluicing and total volume of water sluiced. It is recommended that future research should quantify if altering the sluicing regime increases the proportion of eels that approach and pass through the gravity sluice, and ultimately reduce the proportion that pass through hazardous pumps. Notwithstanding, physical (e.g. fine-mesh screen) and/or non-physical (e.g. acoustics, light, or electric barrier) measures may be required to prevent eel entrainment when the gravity sluice is closed during pump operation.

\section{Acknowledgements}

The study was funded by the Environment Agency, UK. We would like to thank the internal drainage board for access to the pumping station, the local eel fishermen (Terry Smith and his son) for assistance with fish capture, and Dale Webber and Frank Smith (Vemco, Halifax, Canada) for assistance with production of eel position data. 


\section{References}

Baker, N., Haro, A., Watten, B., Noreika, J., Bolland, J.D., 2019. Comparison of attraction, entrance and passage of downstream migrant American eels (Anguilla rostrata) through airlift and siphon deep entrance bypass systems. Ecol. Eng. 126, 74-82. https://doi.org/10.1016/j.ecoleng.2018.10.011

Baker, N.J., Boubée, J., Lokman, P.M., Bolland, J.D., 2020. Evaluating the impact of hydropower on downstream migrating anguillid eels: Catchment-wide and fine-scale approaches to identify cost-effective solutions. Sci. Total Environ. 748. https://doi.org/10.1016/j.scitotenv.2020.141111

Bašić, T., Aislabie, L., Ives, M., Fronkova, L., Piper, A., Walker, A., 2019. Spatial and temporal behavioural patterns of the European eel Anguilla anguilla in a lacustrine environment. Aquat. Sci. 81, 73. https://doi.org/10.1007/s00027-019-0671-y

Bevacqua, D., Melià, P., Gatto, M., De Leo, G.A., 2015. A global viability assessment of the European eel. Glob. Change. Biol, 21, 3323-3335. https://doi: 10.1111/gcb.12972

Baumgartner, L.J., Reynoldson, N.K., Cameron, L., Stanger, J.G., 2009. Effects of irrigation pumps on riverine fish. Fish. Manage. Ecol. 16, 429-437. https://doi.org/10.1111/j.1365-2400.2009.00693.x

Behrmann-Godel, J., Eckmann, R., 2003. A preliminary telemetry study of the migration of silver European eel (Anguilla anguilla L.) in the River Mosel, Germany. Ecol. Freshw. Fish 12, 196-202. https://doi.org/10.1034/j.1600-0633.2003.00015.x.

Bolland, J.D., Murphy, L.A., Stanford, R.J., Angelopoulos, N.V., Baker, N.J., Wright, R.M., Reeds, J.D., Cowx, I.G., 2019. Direct and indirect impacts of pumping station operation on downstream migration of critically endangered European eel. Fish. Manage. Ecol. 26, 76-85. https://doi.org/10.1111/fme.12312 
Brown, L.S., Haro, A., Castro-Santos, T., 2009. Three-dimensional movements of silver-phase American eels in the forebay of a small hydroelectric facility. In: Casselman, J.M., Cairns, D.K. (eds.), Eels at the edge: science, status and conservation concerns, American Fisheries Society Symposium 58, Bethesda, 277-291.

Buysse, D., Mouton, A.M., Stevens, M., Van den Neucker, T., Coeck, J., 2014. Mortality of European eel after downstream migration through two types of pumping stations. Fish. Manage. Ecol. 21, 13-21. https://doi.org/10.1111/fme.12046

Calles, O., Olsson, I.C., Comoglio, C., Kemp, P.S., Blunden, L., Schmitz, M., \& Greenberg, L.A. 2010. APPLIED ISSUES: Size-dependent mortality of migratory silver eels at a hydropower plant, and implications for escapement to the sea. Freshwater Biol. 55, 2167-2180. https://doi.org/10.1111/j.1365-2427.2010.02459.x

Council Regulation (EC) No 1100. 2007. Establishing measures for the recovery of the stock of European eel. Official Journal of the European Union L 248, 17-23.

Durif, C., Dufour, S., Elie, P., 2005. The silvering process of Anguilla anguilla: a new classification from the yellow resident to the silver migrating stage. J. Fish Biol. 66, 1025-1043. https://doi.org/10.1111/j.0022-1112.2005.00662.x

Durif, C.M., van Ginneken, V., Dufour, S., Müller, T., Elie, P., 2009. Seasonal evolution and individual differences in silvering eels from different locations. In Spawning migration of the European eel, Springer, Dordrecht, 13-38.

Eel Regulations. 2009. The Eels (England and Wales) Regulations 2009, available online at http://www.legislation.gov.uk/uksi/2009/3344/contents/made

Egg, L., Mueller, M., Pander, J., Knott, J., Geist, J., 2017 Improving European Silver Eel (Anguilla anguilla) downstream migration by undershot sluice gate management at a 
small-scale hydropower plant. Ecol. Eng. 106, 349-357. https://doi.org/10.1016/j.ecoleng.2017.05.054

Feunteun, E., 2002 Management and restoration of European eel population (Anguilla anguilla): an impossible bargain. Ecol. Eng. 18, 575-591. https://doi.org/10.1016/S0925-8574(02)00021-6

Garcia De Leaniz, C., 2008. Weir removal in salmonid streams: implications, challenges and practicalities. Hydrobiologia 609, 83-96. https://doi.org/10.1007/s10750-008-9397-x

Hothorn, T., Hornik, K., van de Wiel, M.A, Zeileis, A., 2006. A Lego System for Conditional Inference. Am. Stat. 60, 257-263. https://doi.org/10.1198/000313006X118430

Hothorn, T., Hornik, K., van de Wiel, M.A, Zeileis, A., 2008. Implementing a Class of Permutation Tests: The coin Package. Available online at https://cran.r-project.org/web/packages/coin/vignettes/coin_implementation.pdf

Jacoby, D., Gollock, M., 2014. Anguilla anguilla. The IUCN Red List of Threatened Species 2014: e.T60344A45833138.

Jansen, H.M., Winter, H.V., Bruijs, M.C., Polman, H.J., 2007. Just go with the flow? Route selection and mortality during downstream migration of silver eels in relation to river discharge. ICES J. Mar. Sci. 64, 1437-1443. https://doi.org/10.1093/icesjms/fsm132

Okland et al., 2019 Økland, F., Havn, T.B., Thorstad, E.B., Heermann, L., Sæther, S.A., Tambets, M., Teichert, M.A., Borcherding, J., 2019. Mortality of downstream migrating European eel at power stations can be low when turbine mortality is eliminated by protection measures and safe bypass routes are available. Int. Rev. Hydrobiol. 104 (3-4), 68-79. https://doi.org/10.1002/iroh.201801975

Piper, A.T., Wright, R.M., Walker, A.M., Kemp, P.S. 2013. Escapement, route choice, barrier passage and entrainment of seaward migrating European eel, Anguilla anguilla, within 
a highly regulated lowland river. Ecol. Eng. 57, 88-96. https://doi.org/10.1016/j.ecoleng.2013.04.030

Piper, A.T., Manes, C., Siniscalchi, F., Marion, A., Wright, R.M., Kemp, P.S. 2015. Response of seaward-migrating European eel (Anguilla anguilla) to manipulated flow fields. Proc. R. Soc. B. 282, 20151098. https://doi.org/10.1098/rspb.2015.1098

Sand, O., Enger, P.S., Karlsen, H.E., Knudsen, F., Kvernstuen, T., 2000. Avoidance responses to infrasound in downstream migrating European silver eels, Anguilla Anguilla. Environ. Biol. Fishes 57, 327-336. https://doi.org/10.1023/A:1007575426155

Sandlund, O.T., Diserud, O.H., Poole, R., Bergesen, K., Dillane, M., Rogan, G., Durif, C., Thorstad, E.B., Vøllestad, L.A., 2017. Timing and pattern of annual silver eel migration in two European watersheds are determined by similar cues. Ecol. Evol. 7, 5956-5966. https://doi.org/10.1002/ece3.3099

Solomon, D, J., Wright, R., 2012. Prioritising pumping stations for facilities for the passage of eels and other fish, Environment Agency, Final report, 1-49

Tesch, F.W., 2003. The eel. Blackwell Science Ltd., Oxford.

van Keeken, O.A., van Hal, R., Winter, H.V., Tulp, I., Griffioen, A.B., 2020. Behavioural responses of eel (Anguilla anguilla) approaching a large pumping station with trash rack using an acoustic camera (DIDSON). Fish Manag. Ecol. 00, 1-8. https://doi.org/10.1111/fme.12427

Verhelst, P., Buysse, D., Reubens, J., Pauwels, I., Aelterman, B., Van Hoey, S., Goethals, P., Coeck, J., Moens, T., Mouton, A., 2018. Downstream migration of European eel (Anguilla anguilla L.) in an anthropogenically regulated freshwater system: Implications for management. Fish. $\quad$ Res. 199, 252-262. https://doi.org/10.1016/j.fishres.2017.10.018 
Watene, E.M., Boubée, J.A.T., 2005. Selective opening of hydroelectric dam spillway gates for downstream migrant eels in New Zealand. Fish. Manage. Ecol. 12, 69-75. https://doi.org/10.1111/j.1365-2400.2004.00422.x 